\title{
9
}

\section{The Taming of the Jew: Spit and the Civilizing Process in The Merchant of Venice}

Brett D. Hirsch

Jews were murdered by the Nazis and Nazi collaborators by the millions. These are unforgettable realities to me and intrude violently into my reading of the various brutalizations of Shylock ... Even ambiguous, or to many readers of Shakespeare innocent, dramatic moments, such as the account of Antonio's spitting on and kicking of Shylock in the Rialto, fill me with rage. ${ }^{1}$

For readers and audiences of Shakespeare's The Merchant of Venice, Antonio's spitting on Shylock may evoke a range of emotional responses, both subtle and extreme. Audiences may feel disgust and discomfort, guilt and shame, anger and contempt. For Derek Cohen and many modern readers, reception of the play has been 'irrecoverably darkened by history' through 'the lens of atrocity'. ${ }^{2}$ In other contexts, however, audiences may feel enjoyment and, perhaps, even affirmation. A reviewer of a (now notorious) production of the play at the Vienna Burgtheater, opening on 15 May 1943, described the depiction of Shylock as 'the pathological image of the typical eastern Jew in all his outer and inner uncleanness. ${ }^{3}$ If we can only speculate how the audience might have reacted to Antonio's threat to spit on and spurn Shylock again during this production, 'singled out as the most infamous instance of theatre's complicity with the regime during the Nazi period, ${ }^{\prime 4}$ how might Shakespeare's audiences and readers in early modern London have reacted?

Spit and the act of spitting carry distinctive, and often contradictory, meanings across different historical, cultural, and social contexts. Recent scholarship on the history of the early modern body, spanning diverse studies of bodily fluids such as blood, breast-milk, semen, urine, and feces, ${ }^{5}$ as well as natural processes such as belching and farting, ${ }^{6}$ has failed to explore the varied social and cultural attitudes toward spit and spitting. This critical lacuna is all the more curious, given the frequent references 
to saliva and its ejection in the literature of the period. Attitudes toward spit and spitting, like any other bodily fluid and function, offer important insights into early modern notions of propriety and social order, as well as changing perceptions of the body and 'its materiality, its relationships to affect and cognition, its role in enculturation, and its connections to the physical world. ${ }^{7}$

This chapter offers a cultural history of spit, tracing attitudes and symbolic associations from biblical sources and classical antiquity through the medieval and early modern periods, to better understand how Shakespeare's early audiences and readers may have interpreted this recurring motif - this staged transgression - in the play. It offers a reading of The Merchant of Venice in which Shakespeare's treatment of spit and spitting heightens the dramatic tensions of his play, toys with the expectations of his readers and audiences, and adds a further dimension to the already complex relationship between Antonio and Shylock.

\section{The anatomy of phlegm}

The humoral theory of the body, associated with Galen and Hippocrates, dominated medical thinking through the medieval and early modern periods. ${ }^{8}$ According to this model, four fundamental substances or 'humors' constituted all living bodies - blood or sanguis, yellow bile or choler, black bile or melancholy, and phlegm. These corresponded to the four elements (air, fire, earth, water) and seasons (spring, summer, autumn, winter) respectively, and were produced by different organs of the body. 'When Galen and other writers speak about blood,' F. David Hoeniger reminds us, 'one must be careful to distinguish between two meanings of the word,' that is 'blood in the sense of merely one of the four humors' and 'blood as the fluid that includes a mixture of all four (though the humor of blood forms by far the largest part of it). ${ }^{\prime 9}$ Similarly, the term 'phlegm' referred both to one of the four humors and to the clear or whitish secretions thought to originate from the brain and lungs - such as mucus and saliva - in which the humor was predominant. Although various alternatives were advanced during the Renaissance, ${ }^{10}$ humoral theory was not displaced as the dominant medical model in Western culture until the acceptance of germ theory in the nineteenth century. For Shakespeare's audiences prior to the nineteenth century, phlegm, in both senses of the word, occupied a privileged position in the mainstream understanding of living bodies, in sickness and in health.

Whether through climate, diet, descent, or astrological influence, it was thought that most individuals were predisposed to an abundance of a particular humor. With The Merchant of Venice, Douglas Trevor argues, 'Shakespeare's representation of sadness in certain characters begins to evade clear objectal explanation,' suggesting a 'growing familiarity with Galenic readings of the 
passions.' ${ }^{11}$ Audiences and critics familiar with the medical knowledge of the period have long recognized hints of a melancholic disposition in the character of Antonio, who opens the play lamenting:

In sooth I know not why I am so sad, It wearies me: you say it wearies you;

But how I caught it, found it, or came by it, What stuffe 'tis made of, whereof it is borne,

I am to learne: and such a Want-wit sadnesse makes of mee, That I haue much ado to know my selfe.

$(\text { TLN 4-10) })^{12}$

His interlocutors, Salarino and Solanio, suggest possible explanations for his dissatisfaction, but Antonio promptly rejects these; by the end of the play, the audience remains none the wiser about its cause. 'Sadness remains a part of Antonio's personality,' Trevor suggests, 'potentially moored in his [humoral] temperament in ways that have not thus far been entertained in Shakespearean dramaturgy.'13

While critics continue to offer possible explanations for Antonio's otherwise unaccountable melancholy, his humoral disposition may well explain why he is the only character in the play to spit. One of the many symptomatic behaviors of a melancholic was immoderate spitting. According to Helkiah Crooke, 'Common and dayly experience addeth strength to this opinion' that 'melancholy men are all of them sputatores maximi' or 'great Spitters,' and no less an authority than Galen 'reckoneth aboundance of spittle to be the principall amongst Hypochondriacall signes' of the melancholic. ${ }^{14}$ In the logic of humoral theory, an inclination to profuse spitting may be the result of excess melancholy drying out the body, since melancholy, as Thomas Walkington observes, 'either with his coldnes extinguish[es] naturall inherent heat, or with his drines suck[s] up the native moisture. ${ }^{15}$

Shakespeare's original audiences and readers may have readily identified Antonio as a melancholic by virtue of his speech and behavior, onstage and reported. However, an Elizabethan audience, better versed and immersed in the theory (and to them, the physical reality) of the humors, may also have attributed Antonio's troubled actions - such as his spitting - to his melancholy. When Shylock recounts Antonio's abuses against him, a dramaturgy sensitive to the medical knowledge of the period has to acknowledge the possibility that his response - 'I am as like to call thee so againe, / To spet on thee againe, to spurne thee too' (TLN 457-8) - is not only a threat of further volitional acts, but also a statement of the likelihood of their material reoccurrence, given Antonio's humoral condition. 


\section{Spit cultures}

The pioneering anthropological and sociological work of Mary Douglas and Norbert Elias provide a useful theoretical frame. All bodily fluids and excretions, according to Douglas, are implicated in powerful cultural and social anxieties about bodily purity and integrity. In Douglas's model of pollution and taboo, the body is conceived as a bounded system, in which the various substances it produces are symbolically and socially acceptable so long as they remain contained within the confines of body itself. When expelled from the body - whether by natural processes or otherwise - these same substances become symbolically and socially unacceptable, unclean, and impure. In considering the question 'why saliva and genital excretions are more pollution-worthy than tears,' Douglas suggests that 'nasal secretions are not so limpid as tears' and 'more like treacle than water,' and thus 'when a thick rheum oozes from the eye it is no more apt for poetry than nasal rheum. ${ }^{16}$

Since the body and its functions are frequently employed as symbols of social structures and processes, they are also, according to Elias, intimately connected to anxieties about purity and integrity on a broader, collective social level. For Elias, the process of civilization involves the systematic cultural association of undesirable bodily functions - such as spitting - with feelings of fear, guilt, and shame: 'Taboos and restrictions of various kinds surround the ejection of saliva, like other natural functions, in very many societies, both "primitive" and "civilized".' Elias supports this observation by tracing what he identifies as a progressive shift in attitudes towards spitting since the Middle Ages, from medieval restrictions against the ejection of saliva in certain social spaces - such as at the table and washbasin - through to the wholesale proscription of the act itself, reflected in a twentieth-century discussion of the disappearance of the spittoon in modern households. ${ }^{17}$

Elias's historical survey of European attitudes toward spitting is both narrow and selective: what about cultural attitudes prior to the Middle Ages? In her study of shame and social control in biblical Israel, Lyn M. Bechtel has shown how Leviticus 15 reflected and maintained the belief that 'all bodily fluids, once discharged (including saliva), were considered extremely defiling'; accordingly, spitting 'defiled and degraded people and rendered them unclean and socially unacceptable' and 'threatened the person with being cut off from the community. ${ }^{18}$ Elias's survey also elides positive historical attitudes toward spit and spitting: R. Selare has shown that 'curative and medicinal properties have been attributed to saliva throughout the ages and throughout mankind,' and folklore variously credited spit with the 'power to create and transfer life, to cure and prevent so many ills and evils of all kinds, to making binding covenants, to ensure good fortune, and where necessary to take vengeance on one's enemies. ${ }^{19}$ Many of these beliefs circulated in 
medieval and early modern English folklore and proverbial wisdom, or were transmitted via scholastic (and later humanist) studies and translations of classical and biblical sources. The New Testament, for example, describes how Christ cured blindness (Mark 8:22) and deafness (Mark 7:32-7) by applying spit to the afflicted organs, whilst Philemon Holland's 1601 translation of Pliny's Natural History invited vernacular readers to consider the contents of a chapter tantalizingly titled, 'Of certaine Sorceries: and the properties of a mans spittle. Also against Magicians,' which recounts the use of saliva to relieve stiffness, to avert witchcraft, and to increase the efficacy of medicine and charms. ${ }^{20}$

Elias's historical survey also suffers from an assumed universality across the cultures of Europe. In fact, as with other bodily functions, attitudes toward spit and spitting were - and continue to be, if modern conduct manuals for global business etiquette are any indication ${ }^{21}$ - noticeably different between ethnic and national groups. Early modern English travelers frequently recorded how local customs differed abroad. As Anna Suranyi (2008) has noted, Fynes Moryson recorded with some surprise restrictions on spitting in Turkey, where 'it were no small trespasse so much as to spet' in 'their Churches,' or 'in common conuersation,' which 'they take for an offence, as if he that spets were wearie of their company. ${ }^{22}$ Sir John Reresby described houses in the Low Countries as 'neat to an uneasy degree, one scarce daring to stir or spit in them, for fear of disobliging the mistress by disordering them, ${ }^{23}$ whereas Owen Felltham bemoaned their narrow size - 'Their rooms are but severall land boxes' - leaving no room to swing a cat let alone eject saliva: 'you must either goe out to spit, or blush when you see the Mop brought. ${ }^{24}$ Attitudes toward spit and spitting, then, were as much a marker of ethnic and national difference as they were distinctions between social and cultural groups, in early modern England as well as our own time.

Both during and after the long English Reformation, spit and spitting became embroiled in bitter and ongoing theological debates. In a popular anti-Papist tract, Alexander Cooke described how the Catholic ceremony of baptism presumed to mimic the acts of Christ:

The Priest puts his finger into the eares of him who comes to bee baptized, and spittle into his mouth: the putting of his finger into the eares, signifies that the partie to be baptized should haue his eares alwayes open to heare the word of God; and the putting in of spittle into his mouth, signifies, that he should speake roundly and readily of faith, because spittle helpes speech. ${ }^{25}$

'The horror that some Elizabethan protestants expressed at the miscellaneous substances contaminating the Roman practice of baptism,' David Cressy has argued, 'was akin to their aversion to popish images and superstitious gestures. ${ }^{26}$ Reformers were quick to target these practices, and by 
1552 they were successfully expunged. In 1561, John Bale boasted that the new Book of Common Prayer 'alloweth neyther spattle nor salte, creame nor yet stinking oyle, with other pilde peltries of the pope. ${ }^{27}$ Although he had been subjected to the Catholic ceremony, King James VI and I would proudly report later that 'his Mother sent word to the Arch-bishop who did baptize him, to forbeare to vse spittle in his baptisme: For she would not haue a pockie Priest to spit in her childs mouth. ${ }^{28}$ For early modern readers and audiences of The Merchant of Venice, then, spit was potentially serious theological business.

\section{Spitting Jews and stranger curs}

This brief historical survey suggests spit was a potent symbol with both negative and positive cultural associations - cause and cure, curse and charm central to anxieties connected with bodily, social, and theological purity. Before proposing a reading of The Merchant of Venice, however, further examination of two key motifs in the play - the Jew and the dog - and their various cultural associations with spit and spitting in early modern England is required.

Though the Jews were expelled from England in 1290, a rich cultural and material legacy ensured that their presence was felt long before their de facto readmission under Cromwell in the 1650s. Any discussion of the representation of Jews in early modern English culture therefore has to take the indigenous antisemitic textual and visual narratives inherited from England's medieval past into account. ${ }^{29}$ One of the most potent of these images was that of the spitting Jew. According to the Synoptic Gospel accounts of the Mocking of Christ, he was beaten, spurned, and spat upon. ${ }^{30}$ Anthony Bale has shown how, through its incorporation into the iconography of the arma Christi or 'Arms of Christ' - a 'pseudo-heraldic design which depicts the Instruments of Christ's Passion' - the spitting Jew became a 'Jewish image which, if not ubiquitous, occupied a fundamental role in late medieval devotional and cultural imaginations. ${ }^{31}$ Visual representations of the arma Christi survive in late medieval manuscripts, ${ }^{32}$ as well as in the roof bosses, wall paintings, and stained glass of various English cathedrals and churches. ${ }^{33}$ For example, a mid-fifteenth-century roof boss above the chancel arch at St Mary's Church in Clifton, Nottinghamshire, depicts a spitting Jew with a monstrously cleft tongue surmounting a coat of arms bearing Christ's five wounds (Figure 9.1). Similarly, a fragment of a fifteenth-century stained-glass shield at Great Malvern Priory Church in Malvern, Worcestershire, vividly portrays a Jew spitting at Christ (Figure 9.2).

Unsurprisingly, Jews spitting at Christ frequently appear in medieval English drama and poetry. 'Pe Jewes spitte on me spitously,' cries Jesus in the York Doomsday Play. ${ }^{34}$ In the Chester Trial and Flagellation Play, the high priest Annas instructs the Jews to 'Despice [Christ], spurne and spyt. ${ }^{35}$ In 


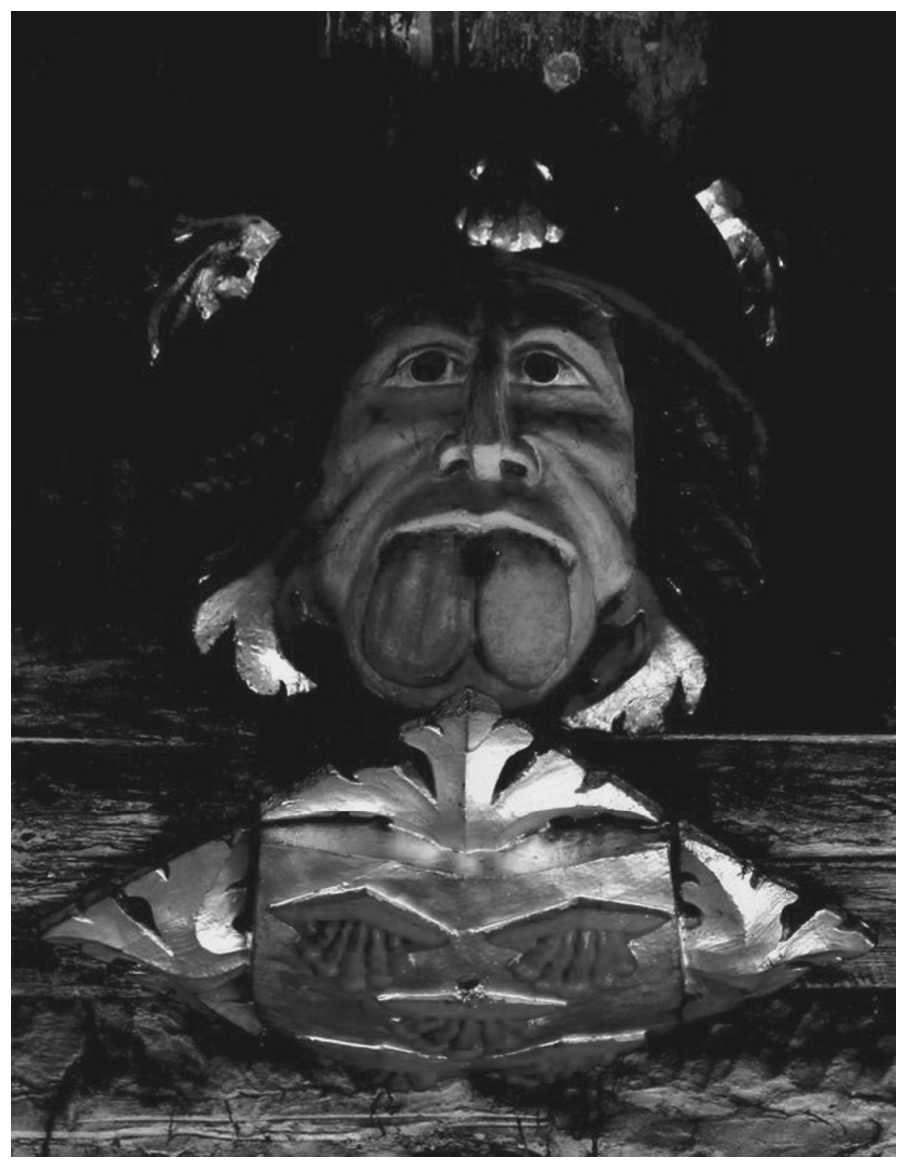

Figure 9.1 Jew spitting on Christ's coat of arms. Roof boss at St Mary's Church, Clifton

Source: Photo by Geoff Buxton. Courtesy of the Diocese of Southwell and Nottingham Church History and Open Churches Project

the Towneley Scourging Play, the Second Torturer announces that he 'shall spytt in [Jesus'] face'; ${ }^{36}$ and, as Clifford Davidson has noted, the Cornish Passion Play includes a stage direction that the Second Torturer is to spit 'in faciem Jhesu. ${ }^{37}$ In The Myrour of Lewed Men, a Middle English metrical translation and abridgement of Robert Grosseteste's Chateau d'Amour, Christ's 'neys smelled of the Iewes snot and foul spitting / That thei cast vpon his face to blode and sweting. ${ }^{38}$ Vivid illustrations of this scene often accompany the arma Christi poems in medieval manuscripts. ${ }^{39}$ For example, an arma Christi poem in a late fifteenth-century English manuscript (Princeton Library MS 


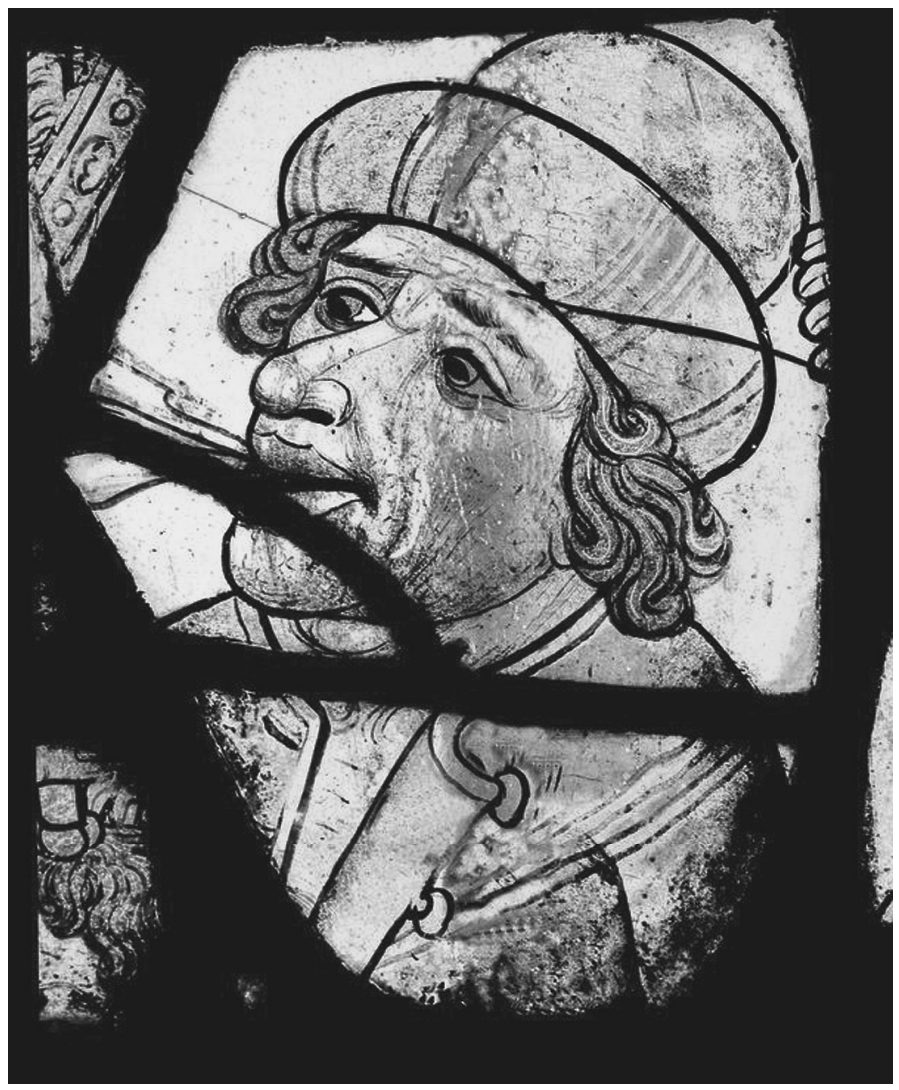

Figure 9.2 Jew spitting at Christ. Stained glass at Great Malvern Priory, Malvern Source: Photo by Rev. Gordon Plumb, Barton upon Humber. Reproduced by kind permission

Taylor 17) includes a detailed miniature of two Jews spitting in Jesus' face alongside the following verse: 'The Iewes that spytte lorde i[n] thy face / All thou suffred and gaue the $[\mathrm{m}]$ grace / That I haue offended or ony me / Forgyue it lorde for that pyte' $(7 \mathrm{v})$.

While the arma Christi was an important source for the motif - particularly in England - other medieval devotional works associated Jews with spitting. James H. Marrow observes, 'Above all it was the spitting upon Christ that seemed to capture the interest of late medieval authors, ${ }^{40}$ and the Speculum humanae salvationis, 'one of the most widely disseminated and influential works of the Middle Ages, ${ }^{\prime 41}$ provides a pertinent example. Written in Latin verse during the early fourteenth century, the Speculum humanae salvationis is an elaborate account of providential history, in which the personalities 
and stories of the Old Testament - including various accretions from legends and folklore - are typological prefigurations of those in the New. One such accretion is the legend of the martyrdom of Hur by spitting, an incident appended to accounts of the Israelites' idolatrous worship of the Golden Calf. The apocryphal incident is described in the Historia scholastica, a twelfthcentury biblical paraphrase by Peter Comestor, as follows:

Seeing that Moses was delayed, the people said to Aaron, 'Make us a god to go before us, for we do not know what has happened to Moses.' [...] Aaron and Hur resisted. But the people were indignant, and tradition has it that they spat in Hur's face, suffocating him with the spittle. ${ }^{42}$

In chapter 19 of the Speculum humanae salvationis, the mocking of Christ is paired with and prefigured by the suffocation of Hur, typologically connecting the pair of martyrs through the shared motif of spitting Jews. The work was later translated into various European vernaculars, in both verse and prose. An early fifteenth-century English translation, The Miroure of Mans Saluacione, describes the analogous martyrdom of Hur in the following verse:

The Jewes, with pair spittings whilk Cristes face defovlide, Be the ydolatiers of the golden veel ware wele prefigurede, For when the Jewes in desert walde make thaym gods fals, Aaron than thaym withstode and Hur, Maries husband, als. Wharefore thay ranne on Hure for his trwe chalenginges, And in dedeigne and dispite choked hym with thaire spittinges. Thay hatid Hure for pat he reproved thaire ydolatrye, And the Pharisens hated Crist, blaming thaire trecherye. ${ }^{43}$

While The Miroure of Mans Saluacione is not illustrated, one-third of the surviving Speculum humanae salvationis manuscripts (which number over 400 ) and all of the early printed editions (of which there are about 20) are, ${ }^{44}$ and their images inspired stained glass, tapestries, and wall paintings in churches and cloisters across Western Europe. ${ }^{45}$ In illustrated versions of the text, the visual parallels between the depictions of the mocking of Jesus and the martyrdom of Hur are striking. ${ }^{46} \mathrm{~A}$ typical example from an early fifteenth-century Dutch blockbook edition juxtaposes the two illustrated scenes side by side, with Jesus and Hur buffeted and spat upon by four Jewish figures (Figure 9.3). As with other pejorative Christian representations of Jews during this period, the biblical Jews of the narrative are visually conflated with contemporary ones. ${ }^{47}$ Just as the spitting Jew in the stained glass fragment at Great Malvern Priory (Figure 9.2) is rendered in contemporary yellow garb - a color associated with Jews after the Fourth Lateran Council of 1215 compelled them to wear yellow badges throughout 


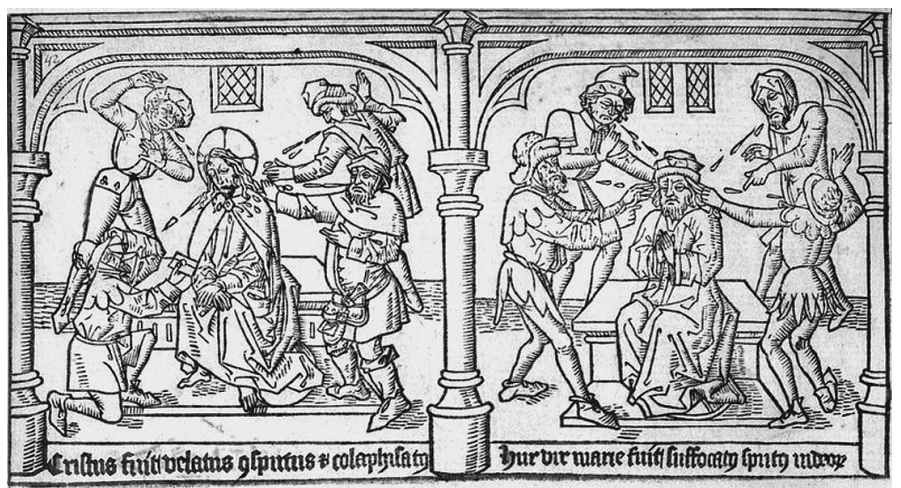

Figure 9.3 The Mocking of Christ and the Martyrdom of Hur. Dutch blockbook edition of the Speculum humanae salvationis, c.1468-79

Source: Bayerische Staatsbibliothek Xylogr. 37, fol. 33v. Courtesy of the Abteilung für Handschriften und Alte Drucke, Bayerische Staatsbibliothek, München

Christendom - the Jews assaulting Jesus and Hur are distinguished by their distinctive medieval attire - the horned hats (pileum cornutum) that Jews were required to wear following the Council of Vienna in 1267.

While the yellow badge was common elsewhere in Europe, English Jews before the expulsion of 1290 were instead required to wear strips of white linen or parchment representing the Mosaic Tablets of the Law. Such laws, enacted to ensure that Jews could be readily identified through distinctive clothing and badges, were 'enforced earlier and more consistently in England than in any other country of Europe. ${ }^{\prime 48}$ Shylock's reference to his 'Iewish gaberdine' (TLN 440) and 'the badge of all our Tribe' (TLN 438) may allude to this legislation, still in force elsewhere in early modern Europe, including Venice, when Shakespeare wrote The Merchant of Venice.

Transmitted through visual and textual culture - whether by way of the arma Christi, the Speculum humanae salvationis, or derivative works of both in various media - the motif of the spitting Jew survived long into the early modern period. In print, theological treatises stressed the associations between Jews and bodily, social, and theological pollution, as accounts of the 'felon Jewes foule and stynkyng' that 'spytte vylaynsly in [Jesus'] fayre vysage, ${ }^{\prime 49}$ of 'the excrements of the Iewes spet vpon the face of our Sauiour, ${ }^{50}$ or the face of Jesus 'besmeared with the filthy spettle of the Iewes $^{\prime 51}$ were readily available to early modern English readers. Devotional literature similarly contrasted the martyrdoms of Jesus and Hur well into the seventeenth century: in his History of the Life and Death of Jesus Christ, Jeremy Taylor describes how the Jews spat at Christ 'with a violence and incivility like that which their Fathers had used towards Hur ... whom they 
choaked with impure spittings into his throat. ${ }^{52}$ In early modern English poetry, John Donne's Holy Sonnet 7 opens with, 'Spit in my face you Iewes, and pierce my side, ${ }^{53}$ while on the contemporary stage Barabas boasts that 'when the offering-Basin comes to me, / Euen for charity I may spit intoo' $t$ ' in Christopher Marlowe's The Jew of Malta. ${ }^{54}$

Given how ubiquitous the image of the spitting Jew appears to have been in late medieval and early modern Christian culture, Elizabethan and Jacobean audiences and readers of The Merchant of Venice may well have expected Antonio to be the victim of Jewish spitting, not its perpetrator. Shakespeare's clever reversal of the idiom operates both as an instance of the ironic adoption by Christians in the play of behaviors stereotypical of the Jews they despise, ${ }^{55}$ and, through the play's analogous rendering of Antonio as Christfigure, ${ }^{56}$ as an ironic inversion of the Passion narratives themselves.

Shakespeare's reversal of the spitting Jew tradition was certainly atypical of his time, and may even have frustrated the expectations of his original audiences and readers. Modern audiences and readers of The Merchant of Venice, more sensitive to the consequences of intolerance, genocide, and antisemitism - both historical and contemporary - are typically unsurprised by Antonio's spitting at Shylock, and, as a result, overlook the ironic potential of the incident. Productions in which characters other than Antonio spit at Shylock, or in which the Christians spit at other Jews in the play and vice versa, therefore sacrifice the ironic potential of the text - granted, an ironic potential contingent on an historical, religious, and cultural framework no longer available to modern audiences - in order to emphasize more immediate concerns about racial prejudice. Bill Alexander's controversial 1987 production of The Merchant of Venice for the Royal Shakespeare Company was described as 'an epidemic of spitting' from both sides, in which 'the spitting never seemed to stop. ${ }^{57}$ Reflecting upon the same production, James C. Bulman noted how 'spitting punctuates most of the key moments of victimisation,' right from its opening:

It begins at the outset when, silent and silhouetted upstage, Tubal stands alone. Salerio and Solanio enter across the bridge and, unprovoked, spit on him as they pass. That one simple action sets the tone for the whole play. They spit on him again when he enters to Shylock ... , this time baiting him as well with a chorus of 'Jew, Jew, Jew!' ... It is fitting, then, that when Shylock has gained the upper hand and leads Antonio off to jail, he abuses him in kind. Shylock will have none of Solanio's pleas for mercy ... and as a full stop, he spits. Before leaving, he spits again at the manacled Antonio: the Christians have taught him such behaviour. ... The scene concludes with Solanio spitting in the direction of Shylock's exit. ${ }^{58}$

Other early modern cultural references to various beliefs and practises associated with spit and spitting present a challenge for modern editors, readers, 
and audiences. One of the more curious practices widely referenced in the literature of early modern England is that of spitting into a dog's mouth. At the end of Scene 3 of Thomas Middleton and Thomas Dekker's The Roaring Girl, following the entrance of Gallipot and Tiltyard and their servants 'with water Spaniels and a ducke,' a stage direction indicates that Tiltyard 'spits in the dogs mouth,' a direction accompanied by the onomatopoeic utterances 'hum - pist - pist' and 'puh - pist - hur - hur - pist.' 59 As Teresa Grant has shown, this scene 'has created problems for critics because they tend to misunderstand the nature of Tiltyard's spitting in his dog's mouth,'60 highlighting an earlier critic's erroneous suggestion that 'Gallipot has one of the dogs trained to serve as a cuspidor, for he spits in the dog's mouth, a scene which must have brought a storm of laughter from the groundlings. ${ }^{61}$ The original audience, Grant rightly notes, 'probably thought this a quite normal way to behave around a dog. ${ }^{62}$ Recent editors of the play variously gloss the stage direction as 'a common way of showing affection to dogs,' 'a friendly gesture,' and an 'expression of affection toward and means of befriending a dog. ${ }^{63}$

The practice of spitting into a dog's mouth - so vividly described (and presumably enacted) in The Roaring Girl - was acknowledged as an important aspect of training in hunting manuals of the period. For example, in The Gentleman's Recreation, Nicholas Cox's advice on hunting, hawking, fowling, and fishing, collected 'From ancient and modern Authors Forrein and Domestick, and rectified by the Experience of the most Skilfull Artists of these times,' a chapter on 'How to train a WATER-DOG, and the use thereof recommends

For the Training [of] this Dog, ... You must also use words of Cherishing, to give him encouragement when he does well: and in all these words you must be constant, and let them be attended with spitting in his mouth. ${ }^{64}$

This method of engendering affection and reinforcing good behavior in dogs attracted the attention of satirists, such as Ulpian Fulwell, who incorporated it into his (otherwise commonplace) derision of flatterers as fawning spaniels:

[T]hey make you their instrument to fetch and bringe vnto them such commodities, as you by the corrupting of your conscience may compasse, and for your labour they spitte in your mouth. ${ }^{65}$

The practice was also prescribed as a means of pacifying an unruly dog. In a pamphlet relating his experience of debtors' prison, William Fennor reminds his readers that just as 'when a poore man comes nigh a churlish mastiffe he must not spurne him if he mean to go quietly by him, but flatter and stroake 
him on the backe, and spit in his mouth,' so must potential 'Prisoners if they meane not to bee prickt with a Iaylors thorny disposition ... vse him gently,' or, 'if he will not bee bitten with his currish and dogged vsage,' to 'giue faire words and sometimes ... flinge a soppe or two into his gaping and all-deuouring iawes. ${ }^{166}$ Similarly, in the enlarged version of The Malcontent by John Marston and John Webster, the newly added clown figure Passarello remarks, 'Ile dog my Lord, and the word is proper: for when I fawne vpon him hee feedes me; when I snap him by the fingers, hee spittes in my mouth. ${ }^{67}$

Whether intended to bestow calm or engender affection, this 'commonplace of Renaissance dog handling ${ }^{\prime 68}$ is undoubtedly the source of the proverb, 'spit in his mouth and make him a mastiff. ${ }^{169}$ However widespread the practice may have been when handling hounds, some commentators deemed its application in other contexts inappropriate. In his Divine Dialogues, Henry More has the character of Hylobares stress to his companion Cuphophron the importance of context in 'the exercise of Animal Functions of Passions,' which,

To spit is one of the Animal Functions, good and usefull in it self, and to spit into the mouth of a Dog and clap him on the back for encouragement, is not indecorous for the man, and gratefull also to the Dog.

'But,' Hylobares continues, 'if any one had gone about to spit into Cuphophron's mouth, and clap him on the back' for encouragement, 'he would have thought it an intolerable absurd thing, and by no means to be suffered. ${ }^{70}$

\section{Near misses on the Rialto}

In his elegant reading of the play, Bruce Boehrer persuasively argues that Shylock is 'relentlessly bestialized by the language of [Shakespeare's] play ... through an incessant identification with dogs and curs':

This strain of metaphor is brutally overdetermined; during Shylock's first appearance on stage, he is associated with the words dog and cur five times within seventeen lines of blank verse ... Later, this same pattern of reference recurs in the intermittent insults of Solanio and others ... Shylock himself adopts this vocabulary in his vengeful asseveration, 'Thou call'dst me dog before thou hadst a cause, / But since I am a dog, beware my fangs. ${ }^{171}$

As Boehrer notes, the 'dog as social metaphor' performs three functions, namely, 'the notion of the dog as intimate friend or companion,' 'the identification of dogs with slaves and other abjected individuals,' and 'the association of dogs with predatory outsiders. ${ }^{72}$ Jews fell under both of the latter, 
negative social categories in the early modern English imagination: an abject and cursed nation that stubbornly refused to recognize Christian truth, and as attested to by accusations of host desecration, the kidnap and crucifixion of Christian children in mockery of the Passion, the ritual use of Christian blood, sorcery, cannibalism, male menstruation, the poisoning of wells and spreading of infectious disease, and financial exploitation through coin-clipping and usury - a socially, morally, and physiologically aberrant people who actively sought the destruction of that truth. ${ }^{73}$ Boehrer also usefully teases out the ways in which patterns of animal identification in the play not only operate to figure various kinds of social relations, but also how they signal their symbolic inversion. Shylock's accusatory speech during the trial scene, in which he reminds his Christian interlocutors 'You haue among you many a purchast slaue, / Which like your Asses, and your Dogs and Mules, / You vse in abiect and in slauish parts' (TLN 1996-8), 'accomplishes an interesting reversal of the play's overall patterns of metaphorical association,' whereby

As Shylock's identification with dogs includes him in an underclass composed of slaves and other nonpersons, so the bond of flesh inverts the standard relation between slavish Jew and free Christian by asserting Shylock's title to the prerogatives of the latter. Thus as the relations between Jews and Christians are reversed, each term acquires the qualities and associations of its opposite. ${ }^{74}$

Boehrer does not consider Shakespeare's use of spit and spitting in his otherwise careful analysis of The Merchant of Venice's canine imagery. As noted in the previous section, the reversal of the idiom of the Jew spitting at Christ offers an instance of 'the exchange of places between Antonio and Shylock ${ }^{\prime 75}$ that structures the play. However, there is one more inversion that early modern audiences and readers may have noted in the play's treatment of spit and spitting.

If Shylock is figured as a dog, then Antonio symbolically adopts the role of dog-trainer. Just as Shylock is repeatedly stigmatized as a dog in the play a word frequency count reveals that he is referred to as 'dog' seven times, 'cur' three times, and 'currish' twice - Antonio's spitting at Shylock is not a singular occurrence: he has 'spet vpon [Shylock's] Iewish gaberdine' (TLN 440), 'void[ed his] rume vpon [Shylock's] beard' (TLN 445), and 'spet on [Shylock] on Wednesday last' (TLN 453). While it is certainly possible to interpret these outbursts as references to the same event - Shylock's predisposition to verbal repetition is well documented ${ }^{76}$ - the text clearly suggests that it is 'many a time and oft / In the Ryalto' that Antonio has 'rated' and 'spurn'd' Shylock (TLN 434-5, 454) and, as Antonio makes clear in his response, he is 'as like ... to spet on [Shylock] again' (TLN 458). The areas on which Antonio voided his rheum - Shylock's gabardine (an 'vpper frocke' or short cloak) ${ }^{77}$ and beard - are also significant. If we suppose, according 
to the accepted practices of Renaissance dog handling, that the intended target of Antonio's spitting was Shylock's mouth, then Antonio's failure to do so symbolically signals his failure to engender affection in or otherwise pacify the unruly dog - to train the Shylock-dog, to tame the Jew. So too, if Shakespeare's clever inversion of the spitting Jew idiom frustrated the expectations of his original audiences and readers, then Antonio's apparent inability to successfully spit into the mouth of the 'dogge Iew' (TLN 1069) and become its master certainly did. Just as his spit fails to hit its target, Antonio's other attempts at Christian instruction - his exegesis of the Jacob and Laban story (TLN 398-422), for instance - fall on deaf ears. As a result, Shylock remains a 'stranger curre' (TLN 446) - a 'predatory outsider' rather than an 'intimate friend or companion' in Boehrer's terms - until such times as Portia, with the full power of the laws of Venice behind her, compels him to convert his 'currish spirit,' narrowly avoiding the fate of the wolf 'hang'd for humane slaughter' (TLN 2042-3).

\section{Notes}

1. Cohen (2003: 64).

2. Ibid.

3. Quoted in Hortmann (1998: 135).

4. Hortmann (1998: 135). On the reception of Shakespeare in Nazi Germany, see also Bonnell (2010), Habicht (1989), and Symington (2005).

5. On blood, see Feerick (2010), Paster (1993), and Peterson (2010). On breast-milk, see Salmon (1994) and Trubowitz (2000). On semen, see Fissell (2004) and Laqueur (1990). On urine and feces, see Boehrer (1997) and Tate (2004).

6. See Appelbaum (2006) and Thomas (2010).

7. McDowell (2006: 778).

8. See Lindemann (2010), Siraisi (1990) and Wear (2000).

9. Hoeniger (1992: 141).

10. See Debus (1977), Elmer (2004) and Pagel (1982).

11. Trevor (2004: 69).

12. Quotations from Shakespeare are taken from The Norton Facsimile (1968), cited parenthetically by through-line-number (TLN) of that edition.

13. Trevor (2004: 70).

14. Crooke (1615: R3 $\left.{ }^{\mathrm{v}}\right)$. See also Haworth (1680: $\mathrm{H} 2^{\mathrm{r}}$ ).

15. Walkington $\left(1639: \mathrm{I} 2^{\mathrm{v}}\right)$.

16. Douglas (1966: 126).

17. Elias (1978: 1.157-8 and 153-6).

18. Bechtel (1991: 59). All biblical references are to the Geneva Bible (1572).

19. Selare (1939: 349 and 366).

20. Pliny (1601: $\left.2 \mathrm{C} 6^{\mathrm{r}}-2 \mathrm{D} 2^{\mathrm{v}}\right)$.

21. Global Business Etiquette advises its (North American) target readership that 'Spitting on the street is unacceptable behavior in England but is acceptable in China' (Martin and Chaney (2012: 106)).

22. Moryson (1617: $\left.3 \mathrm{H} 3^{\mathrm{v}}\right)$.

23. Reresby (1904: 137). 
24. Felltham (1652: B3 ${ }^{\mathrm{r}}$ ). With the motto non seria semper ('not always serious') on its title page, Felltham's remarks should perhaps be taken in a more humorous vein.

25. Cooke (1628: M4 ${ }^{\mathrm{r}}$ ).

26. Cressy (1997: 136).

27. Bale (1561: S2 ${ }^{\mathrm{v}}$ ). Earlier, Bale includes 'to bespattle children in baptisme' amongst a list of offensive Catholic liturgical practices $\left(\mathrm{D}^{\mathrm{r}}\right)^{\mathrm{r}}$.

28. Reported in Cooke (1628: M3 $\left.{ }^{\mathrm{v}}\right)$. The reference to the pox, whether insult or statement of fact, raises the important issue of infectious disease and the figuring of the mouth as an ingress or egress for (physiological or theological) pollution.

29. On the representation of Jews in medieval and early modern English culture, see Adelman (2009), Bale (2006), Hirsch (2013), and Shapiro (1996).

30. See Matthew 26:67, 27:27-30 and Mark 14:65, 15:16-19; compare Luke 22:63-5.

31. Bale (2006: 145).

32. See Berliner (1955), Hirsh (1996) and Suckale (1977).

33. A spitting Jew appears on the early sixteenth-century vaulting bosses in Winchester Cathedral. Clifford Davidson also observes a spitting Jew 'represented in a wall painting above an altar formerly under the East Window in York Minster' (2007: 166 n. 114). Brian Coe notes 'large sets' of stained glass depictions of the Arma Christi in churches at 'Westwood, Wiltshire, Winscombe, Somerset, and Laneast, Cornwall' (1981: 66).

34. British Library Add. MS 35290, 264v .

35. British Library MS Harley 2124, 81 ; Huntington Library MS 2, $93^{\mathrm{v}}$.

36. Huntington Library MS HM $1,79^{\mathrm{v}}$.

37. Quoted in Davidson (2007: 166, n. 114).

38. British Library MS Egerton $927,10^{\mathrm{v}}$.

39. See Bale (2006: 175) and Rossell Hope Robbins (1939). A number of these poems are available in Morris (1871).

40. Marrow (1979: 132).

41. Wilson and Wilson (1984: 9).

42. Quoted in Marrow (1979: 132.)

43. Beeleigh Abbey MS Foyle, $26^{\mathrm{v}}$, as transcribed by Henry (1987: 11. 2161-8).

44. See Silber (1982) for a catalogue of manuscript and print editions.

45. See Chilvers (2004: 666) and Crowther (2010: 26-7). Richard Marks has identified images based partly on those from the Speculum humanae salvationis in the typological juxtapositions of Old and New Testament scenes in the fifteenth-century stained glass at Great Malvern Priory, Worcestershire (1993: 68).

46. So striking, as Marrow notes, that textual and visual examples survive of the 'merging of type and antitype' in which the Jews spit into Christ's mouth as if to suffocate him as they did Hur (1979: 133-4).

47. On the pejorative representation of Jews in medieval art, see Mellinkoff (1993), Schreckenberg (1996), and Strickland (2003).

48. Roth (1964: 95).

49. De Roye (1489: B2 $\left.{ }^{\mathrm{r}}\right)$.

50. Adams (1619: 2V5r).

51. Hall (1608: D5 ${ }^{\mathrm{r}}$.

52. Taylor $\left(1649: 3 \mathrm{I} 1^{\mathrm{v}}\right)$.

53. Donne (1633: F2 ${ }^{\mathrm{v}}$ ).

54. Marlowe (1633: $\left.\mathrm{D} 4^{\mathrm{r}}\right)$.

55. Bale makes this important observation (2006: 227, n.16), but tucks it away in his notes and does not develop it further. 
56. For example, R. Chris Hassel, Jr. offers an ironic reading of Antonio as 'the archetypal Christ' with Shylock taking 'Antonio's Christ-likeness so literally that he pursues a frustrated communion upon his literal body and blood' (21). Barbara K. Lewalski observes in Antonio's 'baring his breast to shed his blood for the debt of another' a continuation of an 'identification with Christ occasionally suggested at other points in the play' (1962: 339).

57. Gross (1994: 332).

58. Bulman (1991: 124).

59. Middleton and Dekker (1611: D4 ${ }^{\mathrm{r}}$ ).

60. Grant (2007: 107).

61. Wright (1927: 665).

62. Grant (2007: 107).

63. Knowles (2001: 398, n. 372), Bevington et al. (2002: 1398, n. 417), and Kahn (2007: 741, n. 424).

64. Cox $\left(1674: \mathrm{A}^{\mathrm{r}}\right.$ and $\left.\mathrm{P} 7^{\mathrm{v}}-\mathrm{P} 8^{\mathrm{r}}\right)$.

65. Fulwell (1579: I3 $\left.{ }^{\mathrm{v}}\right)$. See also Taylor (1630: G2) and Lodge (1596: A3 $\left.{ }^{\mathrm{v}}\right)$.

66. Fennor (1617: L1 $\left.{ }^{\mathrm{r}}\right)$.

67. Marston and Webster (1604: E3 $\left.{ }^{\mathrm{v}}\right)$. See Grant (2007: 108).

68. Grant (2007: 109).

69. Tilley (1950: M1259).

70. More (1668: T6 $\left.{ }^{\mathrm{v}}\right)$.

71. Boehrer (1999: 161).

72. Boehrer (1999: 163).

73. Representative studies of these narratives include Gregg (1997), Rubin (1999), and Trachtenberg (1943).

74. Boehrer (1999: 162).

75. MacCary (1985: 161).

76. See Gross (1994: 55) and Palfrey and Stern (2007: 193-6).

77. Florio (1598: F2v). 